\title{
Bulletin of the International Union against the Venereal Diseases and Treponematoses
}

\section{0th General Assembly, Berlin, German Democratic Republic, 6-10 June 1980}

\begin{abstract}
The success of the 30th General Assembly was due to the excellent organisation of Obermedizinalrat, Chefartzt Dr G Elste, and his team. They were ably supported by the local authorities, and in particular the Union was honoured by the Minister of Health, who welcomed the participants at a cocktail party in the Ministry of Health.

The Dermatological Society of the German Democratic Republic invited the participants to a reception, at which Dr R R Willcox (London) and Professor Dr A Luger (Vienna) were presented with scrolls as honorary members of the Society by the president, Professor Dr Schubert.
\end{abstract}

The General Assembly took place on 10 June and was preceded by a meeting of the executive committee on 6 June. The president, Dr R D Catterall, opened the session by paying tribute to the work and the outstanding services of the late $\mathrm{Dr} H$ Delune. All those present rose in silent tribute to his memory. Thanks were then expressed to all members who represented the Union at the various meetings of international societies.

The reports of the regional director of Europe (Dr A Siboulet), of Africa (Dr A O Osoba), of Latin America (Dr Corintho Santos), and of South-east Asia (Dr P Vejjabul) were concerned mainly with regional activities and problems and demonstrated their enormous endeavours to combat the problem of venereal diseases in these regions. All the regional directors and in particular the regional director of Africa (Dr A O Osoba), of Latin America (Professor Dr Corintho Santos), and of Europe (Dr A Siboulet) were congratulated by the president on their successful efforts in anti-VD activities by editing journals, organising local meetings, and informing the population, thus creating more awareness of the dangers of the spread of venereal diseases. Their diligent work for the Union was especially appreciated.
A new list of members is being prepared by Dr P Bakker, who has taken on the burden of collecting and assimilating all necessary information. The president thanked Dr Bakker on behalf of the Union.

The statutes and by-laws of the Union no longer fully cover the actual requirements for 1980 and the following years, and $\mathrm{Dr} T$ Guthe has provided and amended a draft, which is now under consideration. The president noted the debt which the Union owed to Dr Guthe.

The unfortunate death of four members of the executive committee (Dr B Webster, USA; Dr I Petkov, Bulgaria; Dr K Kiraly, Hungary; and $\mathrm{Dr} \mathrm{H}$ Delune, Belgium) resulted in four vacancies on the committee. Drs H Kouri (Puerto Rico), A Lassus (Finland), P Mikhailov (Bulgaria), and $P$ Wiesner (USA) were nominated as new members and were unanimously elected by the General Assembly.

The members of the Union were informed that the French name of the Union will be changed from "Union Internationale contre Le Péril Vénérien et Les Tréponématoses" to "Union Internationale Contre Les Maladies Vénériennes et Les Tréponématoses'". The legal steps have been initiated and will be executed by Dr P Durel (Paris) and by $\mathrm{Mr}$ Pfeiffer (Paris), who is the legal consultant of the Union.

Co-operation with the World Health Organisation is to be intensified since the appointment of Dr G Causse (WHO Chief Medical Officer, Bacterial and Venereal Infections, Division of Communicable Diseases) as liaison officer between the Union and WHO. Dr Causse was kind enough to accept this appointment. Dr André Siboulet has at the same time agreed to become a liaison officer to the International Society of Gynaecology. Both nominations were ratified by the General Assembly.
Closer co-operation with the International League of Dermatological Societies has been initiated by an exchange of the protocols of the executive committee meetings between the president of the League, Professor Dr Braun Falco $c$ (Munich, German Federal Republic) and the secretary-general of the Union, $\mathcal{G}$ Professor A Luger.

Dr Jimmy Jefferiss, who had for many years been a tower of strength for the $\bar{c}$ Union and was a most effective treasurer and active secretary-general, has been pro- $\overparen{D}$ moted to honorary member of the IUVDT.

The treasurer (Professor Dr D Petzoldt, Heidelberg, German Federal Republic) reported on the financial situation and stressed that the costs for the increased activities could no longer be covered by the present contributions. He noted that these contributions had remained unchanged for the past 30 years. It has been agreed to raise the individual subscription from US $\$ 10$ to US \$20. The treasurer's report was adopted by the meeting and the president thanked Dr Petzoldt for his work for the Union.

The president congratulated all those associated with the scientific programme. Ninety-three papers were submitted and 70 were read during the scientific sessions. These were well attended by the participants.

The president announced that an invitation had been received from $\mathrm{Dr} W \mathrm{H}$ Verling to hold the next general assembly in Dublin and the meeting accepted this kind invitation. The next general assembly will be held in Dublin in 1982.

The next executive committee meeting will be held in San Juan in Puerto Rico in October 1981. The Union will thereby sponsor and support the regional meeting 0 of the Latin American branch, which will also be taking place in Puerto Rico in October 1981. 